\title{
Two Measures of Reserves: Why Are They Different?
}

\author{
R. ALTON GILBERT
}

B

OTH the Board of Governors of the Federal Reserve System (BOG) and the Federal Reserve Bark of St. Louis (St. Louis) pablish series on the reserves of depository institutions that have similar descriptions. Each reserves series is adjusted both for the effects of reserve requirement changes and for seasonal influences. ${ }^{1}$

Thongh these series have similar descriptions, their growth rates often differ substantially, especially over periods as short as a month (table 1). For instance, in the three years ending in December 1982, the difference between monthly growth rates of the two reserves series (absolute value) averaged 8.6 percentage points. Average differences in growth rates were much smaller over periods longer than a month (chart 1). Absolute value of differences in quarterly growth rates, for example, averaged 3.2 percentage points over the years $1980-82$, while the differences in growth rates over four-quarter periods averaged 1.3 percentage points.

The BOG revised its total reserves series in May of this year. That revision primarily reflects new methods of seasonal adjustment. The revision to total reserves (BOG) essentially has no effect on the average difference between growth rates of the two reserves series. For instance, the average difference in monthly

\footnotetext{
${ }^{I}$ Each of these institutions also publishes a measure of the monetary base. This paper andyzes the reserves series from these two Fed. eral Reserve sources, since financial analysts generally focus on the reserves series in monitoring Federal Reserve actions that influence money growth. For earlier discussions of monetary base and reserves measures, see R. Alton Gilbert, "Revision of the St. Lovis Federal Reserve's Adjusted Monetary Base," this Review (December 1980), pp. 3-10; John A. Tatom, "Issues in Measuring an Adjusted Monetary Base," this Review (December 1980), pp. 11-29, and Albert E. Burger and Robert H. Rasche, "Revision of the Monetary Base," this Review (July 1977), pp. 13-28.
}

growth rates over the 36 months ending December 1982 was 8.4 percentage points based on data available just before the recent revision in total reserves (BOG), compared with 8.6 percentage points with the revised data.

Large differences in the growth rates of these reserves series make things difficult for those who attempt to monitor the influence of Federal Reserve actions on money growth. Large differences in these growth rates also create public concern that data from one, or possibly both, of the sources have been mea* sured incorrectly; this is especially troublesome during periods when there are major changes in reserve requirements or the activities of depository institutions. The purpose of this paper is to describe the two methods of measuring the monetary base and reserves and to analyze the effects of differences in the methods of measurement on the growth rates of the reserves series. $^{2}$

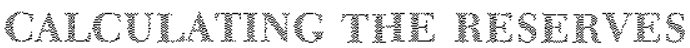 SETRTS}

\section{2ye St. Lowis Sories}

Banc data the sonroe base - - The basic series used in calculating the St. Louis monetary base and reserves series is the source base; it equals reserve balances of depository institutions with Federal Reserve Banks plus total currency in circulation, whether held by depository institutions or the public. The source base

\footnotetext{
The text discusses the procedures for producing these measures of reserves, while the appendix provides a more detailed description. This paper does not select one series as a more appropriate or useful measure of reserves.
} 
Table 1

Growth Rates of the Reserves Series

(compounded annual rates of change, seasonally adjusted)

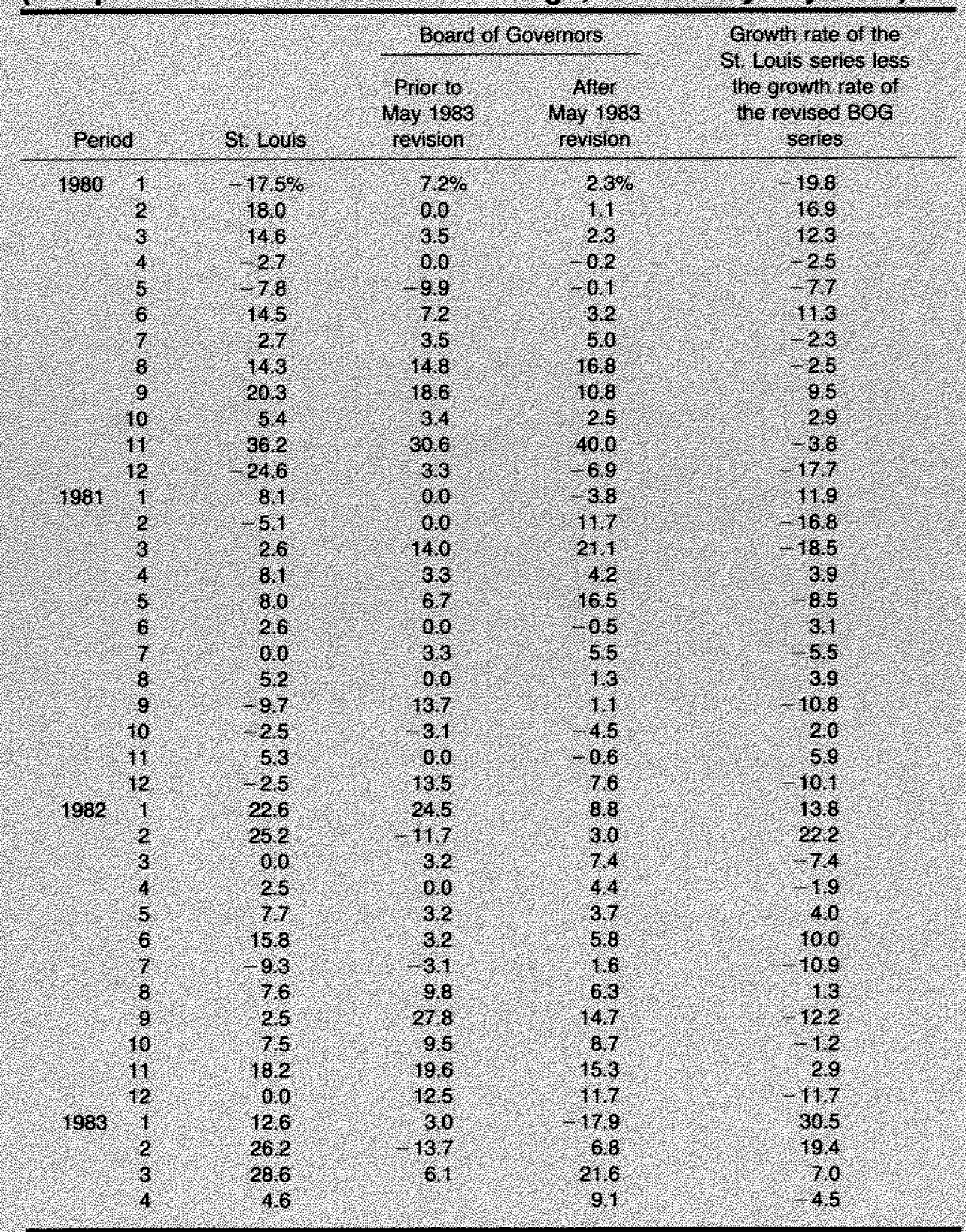

is derived from the combined balance sheets of the Federal Reserve Banks and the U.S. Treasury. It reflects the combined actions of the Federal Reserve and the U.S. Treasury that affect the amount of currency held by the public and reserves of depository institutions.
Whethod of reserve ad wotment - The source base, by itself, does not take into account another Federal Reserve action that affects the money stock: changes in reserve requirements. When reserve requirement ratios are lowered (raised), a given amount of source base can support a higher (lower) level of the money 


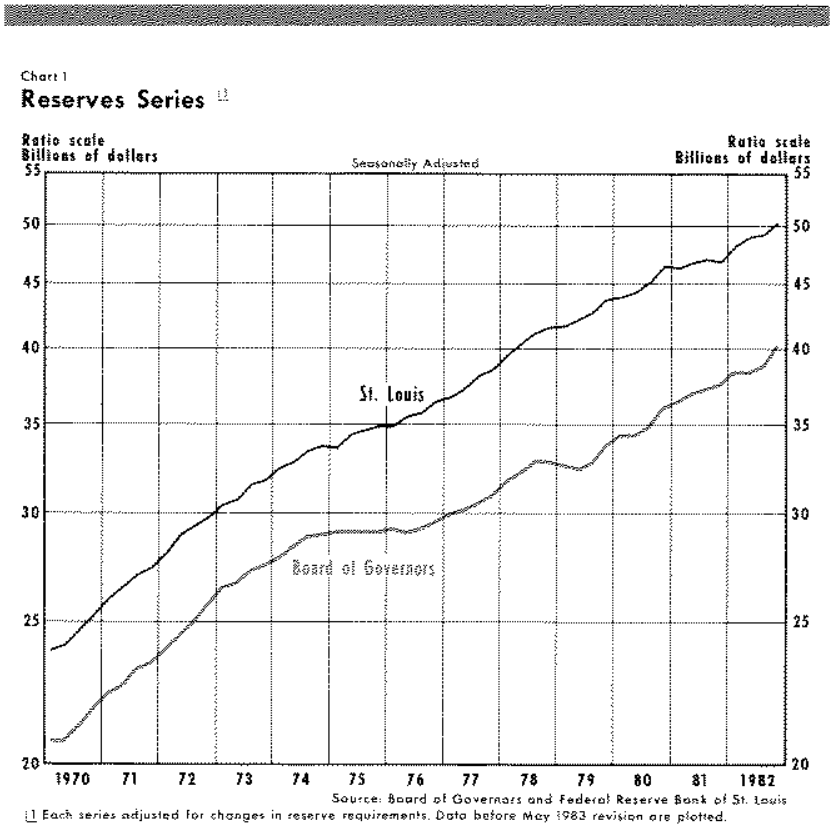

stock, holding constant all other factors that influence the relationship between the money stock and the source base.

To reflect the effects of changes in reserve requirements, the source base is adjusted for the amount of reserves released or absorbed by these changes. This adjustment involves adding a reserve adjustment magnitude (RAM) to the source base, which produces a measure called the adjusted monetary base. RAM is simply the difference between what required reserves would have been (given current deposit liabilities) if a base period's reserve requirements were still in effect and the reserves that are actually required (given current reserve requirements). Adding $\mathrm{RAM}$ to the source base produces a series that indicates what the source base would have been if the reserve requirement ratios had always been those of the base period.

The adjusted resernes areries - The St. Louis Fed derives its adjusted reserves series by subtracting currency held by the public from the adjusted monetary base. Since only currency held by the public is subtracted, vault cash of all depository institutions is included in adjusted reserves.

Sedsonal aly lustanent - The monetary base (source base plus RAM) is seasonally adjusted directly. The adjusted reserves series is adjusted for seasonal influences by subtracting seasonally adjusted currency of the public from the seasonally adjusted monetary base.

\section{Bodrt of Covernors Series}

Busic duth required reserves phus excess reserves The staff of the BOG does not use the source base in deriving its monetary base and reserves series. Instead, it calculates the reserves of depository institutions and adds currency to derive a monetary base measure that is similar to one derived directly from the source base.

Total reserves (BOG) include reserve balances of depository institutions at Federal Reserve Banks. Before December 1980, only the vault cash of member banks was included in the BOG reserves series. As noted previously, the St. Louis reserves series includes the vault cash of nonmember commercial banks, even before those institutions became subject to reserve requirements of the Federal Reserve.

Since December 1980, when the reserve requirement provisions of the Monetary Control Act of 1980 were implemented, all depository institutions have been subject to reserve requirements of the Federal Reserve. Since then, the BOG reserves measure includes all reserves (vault cash and reserve balances at Federal Reserve Banks) of depository institutions whose required reserves exceed their vault cash, plus the required reserves of those institutions that hold vault cash in excess of their required reserves. A large proportion of nonmember depository institutions have held vault cash in excess of their required reserves since December 1980, because their reserve requirements are being increased gradually over eight years to those specified in the Monetary Control Act. The difference between their vault cash and required reserves is excluded from the $B O G$ measure of reserves.

Whenol of reserve edhusment --.. The BOG staff revises its total reserves series after changes in reserve requirements. For the period since the most recent change in reserve requirements, the reserves series equals the sum of required reserves and excess reserve balances. The total reserves series for the period before the most recent reserve requirement change equals excess reserve balances plus the sum of four required reserves series, each for a different type of institution and type of deposit.

Each of these four series is adjusted for breaks due to changes in reserve requirements by use of a ratio method. When reserve requirements are changed, required reserves for each of the four series affected are calculated using both the new and old reserve requirements. The levels of required reserves prior to the change are multiplied by the ratio of required reserves under the new requirements to required re- 
serves under the old requirements. ${ }^{3}$ This procedure indicates what reserves would have been if the current structure of reserve requirements had been in effect throughout the entire period, and if the deposit mix within each of the four categories was the same as the present deposit mix.

Prior to the revision in May 1983, the seasonally adjusted total reserves series (BOG) was derived as the sum of two series that each were seasonally adjusted plus three other series that were not seasonally adjusted. The two seasonally adjusted components of total reserves (BOG) were (1) required reserves on the net transaction deposits of member banks, and (2) re quired reserves on the time and savings deposits of member banks. Required reserves on transaction deposits of member banks were calculated by multiplying seasonally adjusted transaction deposits of member banks by the seasonally adjusted average reserve requirement on those deposits. The same method was used to derive seasonally adjusted required reserves on the time and savings deposits of member banks: seasonally adjusted deposits multiplied by their seasonally adjusted average reserve requirements. The following components were included in seasonally adjusted total reserves (BOG) on a not seasonally adjusted basis:

1. Total required reserves of nonmember depository institutions,

2. Required reserves of Edge Act corporations, and

3. Excess reserves.

In the revised series, seasonal factors have been derived directly for required reserves on net transaction deposits of member banks and for required reserves on the time and savings deposits of member banks. The method of multiplying seasonally adjusted deposits by seasonally adjusted average reserve requirements has been discontinued. Also, total required reserves of nonmember institutions are now seasonally adjusted. The required reserves of Edge Act corporations and excess reserves are still included in seasonally adjusted total reserves (BOG) on a not seasonally adjusted basis.

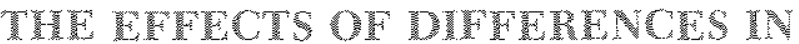

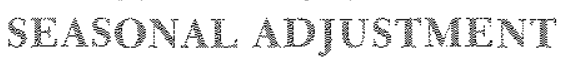

Financial analysts who compare trends in the St. Louis and BOG reserves series typically focus on their

\footnotetext{
${ }^{3}$ Total reserves $(\mathrm{BOC})$ are adjusted for changes in reserve require-
} ments on liabilities of depository institutions other than transaction seasonally adjusted growth rates. Since the methods used to seasonally adjust the two reserves series differ considerably, their growth rates can vary widely over periods of a few months due to this difference alone.

The effects of differences in methods of seasonal adjustment can be analyzed by comparing the differences in growth rates of the two seasonally adjusted reserves series to similar differences in growth rates of the data that are not seasonally adjusted. If some of the variation in differences between growth rates of the not seasonally adjusted data reflects differences in seasonal patterns of the two reserves series, which are factored out through seasonal adjustment, the differences between growth rates of the seasonally adjusted reserves series would be less variable. Differences in the methods of seasonal adjustment, however, may amplify rather than dampen the variation in the differences between the growth rates of these series. In this case, variation in differences of seasonally adjusted growth rates would be greater.

The results in table 2 indicate that, using data available before the recent revision in total reserves (BOG), the differences between growth rates of the data that are not seasonally adjusted are less variable. Some of the differences in seasonally adjusted growth rates of the two reserves series observed in recent years, therefore, must be attributed to differences in methods of seasonal adjustment. Table 2 also indicates that the variability of differences between growth rates of the two seasonally adjusted reserves series is smaller in 1980 and 1982 for the revised data, and the same in 1981 for the old and revised data. Thus, the new method of calculating seasonally adjusted total reserves $(B O G)$ tends to reduce variation in the difference between growth rates of the two reserves series. Therefore, differences between monthly growth rates of the two reserves series may be less variable in the future than those differences observed in the past. ${ }^{4}$

\footnotetext{
or time and savings deposits (such as commercial paper, Eurodollar borrowings and ineligible acceptances) by subtracting from total required reserves the sum of required reserves against these nondeposit liabilities.

${ }^{4} A$ s noted in the introduction, the average difference (in absolute value between monthly growth rates of the two reserves series essentially was tuaffected by the revision of total reserves (BOG). The results in table 2, however, indicate that in two of the three years, the standard deviations of the difference between growth rates of the reserves series were rediced by the revision of total reserves (BOG). The revision reduced some of the more extreme differences between monthly growth rates, while increasing differences in other months. During the 36 months ending in December 1982, the number of months in which the growth rates differed (in absolute value) by more than 20 percentage points declined from 5 to 1 , but the number of months in which growth rates differed by between 10 and 20 percentage points rose from 6 to 15 .
} 
Table 2

Standard Deviation of the Differences between Monthly Growth Rates of the Reserves Series

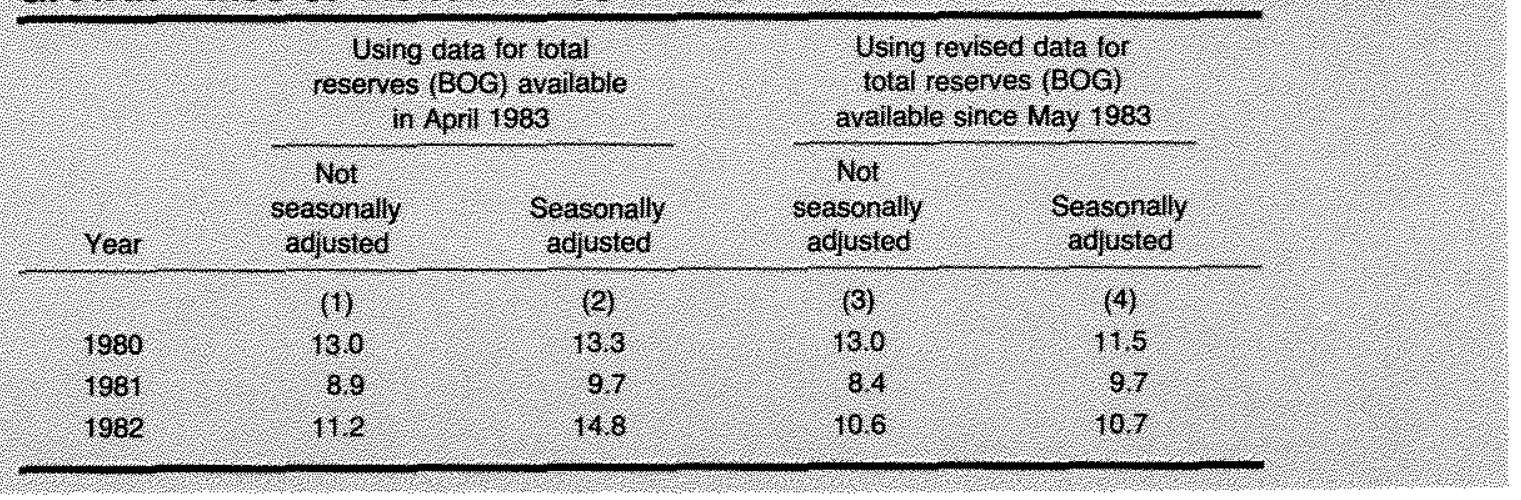

The differences between the average seasonal factors of the two reserves series have a seasonal pattern. ${ }^{5}$ With data available before the recent revision in total reserves (BOG), the average seasonal factors for adjusted reserves (St. Louis) were higher than those for total reserves (BOG) in January, August, September and December (chart 2). The BOG series tended to grow faster (slower) than the St. Louis series during those months in which the line in chart 2 rises (falls).

With the revised data for total reserves (BOG), the difference between average seasonal factors still has a seasonal pattern, but the seasonal pattern has been changed. "The average seasonal factor for adjusted reserves (St. Louis) is especially low relative to that for the revised total reserves (BOG) in January and February. From the relatively low levels for those months, the difference between the average seasonal factors rises to a peak level in August. The pattern of these differences between average seasonal factors in the revised data indicates that total reserves (BOG) will tend to grow faster than adjusted reserves (St. Louis) from around January or February of each year through August, if the differences between seasonal factors continue to have the same pattern as in the past five years.

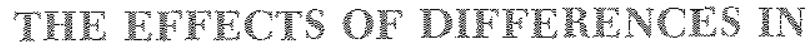 TREATHENT OP VAUT CAST}

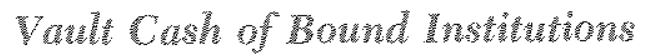

Institutions with required reserves in excess of their vault cash are referred to as "bound institutions." Their

\footnotetext{
The seasonal factors are calculated for each reserves series by dividing the not seasonally adjusted data by the seasonally adjusted data.
}

vault cash is included in the BOG series with a twoweek lag, since it is included as reserves available for meeting reserve requirements two weeks after the vault cash is actually held. In contrast, all currency held by the public and depository institutions is included contemporaneously in the St. Louis series.

This difference in accounting for vault cash between the St. Louis and BOG reserves series tends to produce differences in their monthly growth rates. The magnitude of this effect can be estimated by generating reserves series that treat vault cash identically for bound institutions and calculating the extent to which growth rates of the modified series differ. The easiest way to do this is to subtract the monthly average levels of vault cash held contemporaneously by bound in. stitutions from adjusted reserves (St. Louis), not seasonally adjusted, and add their vault cash held two weeks earlier. When adjusted reserves (St. Louis) are modified in this manner, the standard deviation of the difference between the growth rates of the two reserves series over the 24 months ending in December 1982 is reduced by about 22 percent. Thus, the difference in treatment of vault cash at bound institutions produces sizable differences in monthly growth rates of the two reserves series. This effect is reduced, of course, when periods longer than one month are analyzed; the two series differ by only two weeks in their treatment of the timing of vault cash.

\section{Voult Cash of Nonbound Institutions}

Some relatively large differences between the monthly growth rates of the two reserves series in the past three years have occurred when the reserve requirements of nonmember institutions were increased: December 1980, September 1981 and 
chast 7

Average Difference between Monthly Seasonal Factors

for the Reserve Series!

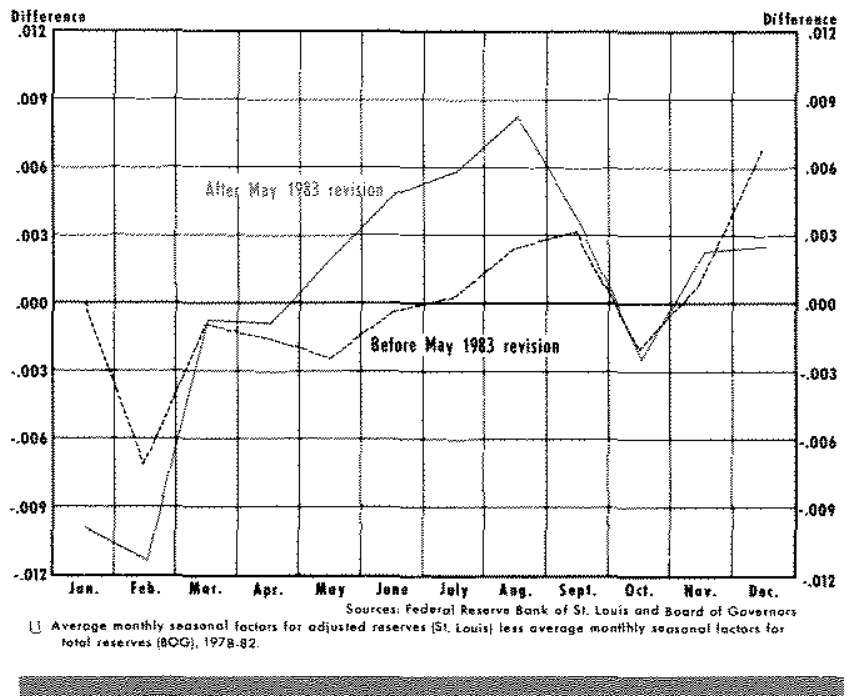

September $1982 .{ }^{6}$ In these months, total reserves (BOG) grew faster than adjusted reserves (St. Louis), with differences in annual growth rates ranging from about 11 to 18 percentage points (table 1 ).

These large differences in monthly growth rates result from differences in the way the two reserves series are adjusted for the effects of changes in reserve requirements of nonbound institutions (those with vault cash that exceeds their required reserves). The RAM component of adjusted reserves (St. Louis) treats the increase in reserve requirements of nonmembers as a policy action that absorbs reserves by the full amount of the increase in required reserves. The BOG method of calculating total reserves treats only the increase in required reserves of nonmembers above their holdings of vault cash as a policy action that absorbs reserves. This difference reduces adjusted reserves (St. Louis) relative to total reserves (BOG) by approximately the amount that excess vault cash declines when nonmember reserve requirements are increased. ${ }^{7}$

\footnotetext{
${ }^{6}$ December 1980 was the first full month in which nonmember depository institutions were subject to reserve requirements of the Federal Reserve.

${ }^{7}$ See the appendix for an algebraic derivation of this result. From August to September 1981 , the rise in total reserves (BOG) less the change in adjusted reserves (St. Louis), on a not seasonally adjusted basis, was about $\$ 600$ million. Excess vautt cash declined by about $\$ 600$ million in September 1981. From August to September 1982 , the BOG series rose by about $\$ 600$ million more than the $S t$. Louis series, approximately equal to the decline in excess vault cash in September 1982. Data on excess vault cash prior to December 1980 are not available.
}

This explains why relatively large differences between monthly growth rates of the two reserves series have occurred when nonmember reserve requirements have been increased. These differences are directly attributable to the difference in methods of adjusting for the effects of changes in reserve requirements.

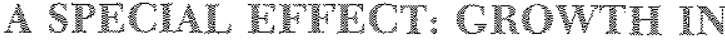 MONE MANET DEPOSTT ACCOUNTS}

The rapid growth of money market deposit accounts (MMDAs) also has produced large differences between the growth rates of the St. Louis and BOG reserves series, since those accounts were introduced in midDecember of last year. ${ }^{8}$ While MMDAs rose to $\$ 320,3$ billion in March, time and savings deposits of all depository institutions (not seasonally adjusted), excluding MMDAs, declined by $\$ 218.5$ billion between last November and March. Although the basic reserve requirements against MMDAs are the same as those against time and savings deposits, the actual required reserves on personal MMDAs at member banks are lower because reserve requirements against MMDAs are not subject to the phase-in that applies to time and savings deposits under the Monetary Control Act of $1980 .{ }^{9}$ With a high proportion of MMDAs being in the personal category, and thus immediately exempt from reserve requirements even at member banks, the shift of funds into MMDAs from other categories of time and savings deposits has reduced the average reserve requirement on total time and savings deposits, inclusive of MMDAs.

No adjustment has been made to total reserves (BOG) for the reserves released as a result of growth of personal MMDAs. In contrast, the growth of personal MMDAs has caused the St. Louis RAM to rise. The

\footnotetext{
${ }^{8}$ MMDAs are exempt from maximum interest rates that may be paid by depository institutions. The two major regulations on MMDAs are a minimum denomination of $\$ 2,500$ per account and a restriction on guaranteeing an interest rate to a depositor for longer than one month. Personal MMDAs (those held by individuals or nonprofit organizations) are exempt from reserve requirements, while nonpersonal MMDAs are subject to a 3 percent reserve requirement.

${ }^{9}$ The basic reserve requirements against MMDAs (currently in effect) and against time and savings deposits (after completion of the phase-in) are 3 percent against nonpersonal deposits and zero against personal deposits. At member banks, time and savings deposits were subject to an average reserve requirement of about 3.3 percent prior to the start of the phase-in, which is now 75 percent complete at such institutions.
} 
category of time and savings deposits used in calculating required reserves with base period reserve requirements includes personal and nonpersonal MMDAs. Deposits in this category have risen since MMDAs were authorized, and required reserves have declined. Both changes have contributed to the growth of RAM. Thus, the shift of deposits from those with positive reserve requirements to personal MMDAs generates a release of reserves. The growth of the St. Louis reserves series since mid-December of last year reflects that release of reserves through a rise in the RAM component. The authorization of personal MMDAs - subject immediately to a full phased-in reserve requirement ratio equal to zero - is viewed as a policy action that has resulted in a release of reserves. This treatment reflects the principle that, if the reserve requirements of the base period currently were in effect, a higher source base would be needed to support the existing levels of checkable deposits and time and savings deposits.

This difference in treatment of MMDAs in reserve adjustment has produced substantially different growth rates in the two reserve series in recent months. From November 1982 through March of this year, adjusted reserves (St. Louis) rose at about a 15 percent annual rate, compared with a 4.5 percent growth rate for total reserves (BOG). Data available prior to the May 1983 revision indicated that total reserves (BOG) rose at a 1.5 percent rate from November of last year through March of this year. Thus, the May 1983 revision raised the growth rate of total reserves (BOG), but not enough to narrow substantially the gap between growth rates of the two reserves series over this period of rapid MMDA growth.

The effect of this difference in treatment of MMDAs on the growth of the reserves series can be gauged indirectly by comparing the rise in the RAM since November of last year to the adjustment to total reserves (BOG) for changes in reserve requirements. Total reserves (BOG), not adjusted for changes in reserve requirements and not seasonally adjusted, declined by $\$ 3,164$ million from November 1982 to March 1983. Total reserves, adjusted for changes in reserve requirements, but not seasonally adjusted, declined by only $\$ 449$ million over the same period. The adjustment for changes in reserve requirements, therefore, is $\$ 2,715$ million. This adjustment reflects primarily the exemption from reserve requirements of the first $\$ 2.1$ million of reservable liabilities at each depository institution, which became effective in late December, and a phased reduction of member bank reserve requirements in early March.

From November 1982 to March, RAM rose by $\$ 4,333$ million. Much of the difference between this figure and the $\$ 2,715$ million figure reflects reserves released through shifts of deposits to personal MMDAs.

\section{CONCLUSIONS}

Although the reserves series of the Federal Reserve Bank of St. Louis and the Board of Governors have similar descriptions, they often display substantially different growth rates from month to month and over periods of several months. There are several reasons for these differences. First, different methods are used to seasonally adjust the series. Growth rates of these series can differ substantially over periods of a few months solely for this reason.

Second, some of the largest monthly differences in growth rates of these reserves series during the past three years have occurred when reserve requirements of nonmembers were increased. At those times, the St. Louis measure of reserves declined relative to that of the BOG. This effect is due to differences in the methods used to account for vault cash and to adjust for the effects of changes in reserve requirements.

Finally, the growth of money market deposit accounts, which have been available at depository institutions since mid-December of last year, has raised the growth of the monetary base and reserves series of the $S$ t. Louis Fed relative to the BOG series. The growth of MMDAs has produced a release of reserves which has been reflected in the growth of the St. Louis series in recent months. In contrast, no adjustment has been made to the $B O G$ series for the release of reserves that has resulted from the policy action of authorizing MMDAs with a zero reserve requirement. 


\section{Appendix}

\section{PROCEWURES FOR CALCULATNG THE WWO MEASUTES OF RESERVES}

\section{S1. Honseries Series}

A reserve adjustment magnitude (RAM) is added to the source base (currency in circulation plus reserve balances of all depository institutions at Federal Reserve Banks). ${ }^{1}$ The base period for calculating RAM is January 1976 through August 1980. Base period reserve requirements are average reserve requirement ratios of member banks over that period on transaction deposits ( 12.664 percent) and on total time and savings deposits (3.1964 percent). RAM is calculated each week by multiplying member bank transaction deposits held two weeks earlier by 0.12664 , adding 0.031964 multiplied by member bank time and savings deposits held two weeks earlier, and subtracting required reserves of all depository institutions for the current week. Deposit liabilities held two weeks earlier are used in calculating RAM because of lagged reserve requirements, under which required reserves for the current week are based on deposit liabilities held two weeks earlier.

Seasonal factors are calculated for the adjusted monetary base (source base plus RAM). Adjusted reserves on a seasonally adjusted basis are calculated by subtracting currency held by the public, seasonally adjusted, from the adjusted monetary base, seasonally adjusted.

\section{Board of Covernors Series}

The following description of the BOG total reserves and monetary base series reflects the methods used to derive the series as revised in May 1983. Total reserves, seasonally adjusted ( $\mathrm{SA}$ ), equal the sum of the following series:

\footnotetext{
${ }^{1}$ Depository institutions maintain clearing balances at Federal Reserve Banks as a means of paying for the fees Federal Reserve Banks now charge for services. Depository institutions receive implicit interest on their clearing balances at the federal funds rate, which may be used to pay the fees on services. Required clearing balances are sabtracted in computing the source base because clearing balances are part of total reserve balances held by depository institutions at Federal Reserve Banks, but are not related to the levels of deposit habilities.
}

(1) Required reserves on net transaction deposits of member banks, SA,

(2) Required reserves on time and savings deposits of member banks, SA,

(3) Total required reserves of nonmember depository institutions, $\mathrm{SA}$.

(4) Total required reserves of Edge Act corporations, not seasonally adjusted (NSA), and

(5) Excess reserve balances held at Federal Reserve Banks, NSA (which excludes required clearing balances).

Each of the four series on required reserves is ad justed for the effects of changes in reserve require ments using a ratio method. At the time of a change ir the reserve requirements that apply to one of the fou: series, required reserves are calculated using the nev and the old requirements. Data for that series of re quired reserves prior to the most recent change it reserves requirements are multiplied by the ratio 0 required reserves under the new requirements to re quired reserves under the old requirements.

The seasonally adjusted monetary base is derived a follows:

(1) Total reserves, adjusted for the effects of changes in reserves requirements, $\mathrm{SA}$,

(2) Plis vault cash of nonmember commercial banks, SA,

(3) Minus required reserves of all nonmember institutions held as vault cash, NSA,

(4) Plus excess vault cash of nonmember depository institutions other than commercial banks, NSA,

(5) Plus currency held by the public, $S A$,

(6) Plus required clearing balances, NSA.

Steps 2 through 5 involve adding components c currency in circulation that are not included in tota reserves (BOG). Thus, this measure of the monetar base includes reserve balances plus total currency i circulation.

\section{METHODS OF PESRRE ADUSTINIT}

This section of the appendix describes the basi differences between the two methods of adjusting th 
series on the monetary base and reserves of depository institutions for the effects of changes in reserve re quirements. To simplify this illustration, the only differences between the St. Louis and BOG series are assumed to be differences in methods of adjusting for the effects of changes in reserve requirements.

The illustration is based on the following assumptions:

1. The liabilities of all depository institutions are subject to one reserve requirement ratio.

2. The base period for the reserve requirement ratio used in calculating RAM (St. Louis series) is designated as period 1 ; it immediately precedes the current period, designated as period 2 .

3. The reserve requirement ratio is different in the current period (period 2) from what it was in the prior period (period 1).

The following symbols are used in describing the methods of reserve adjustment:

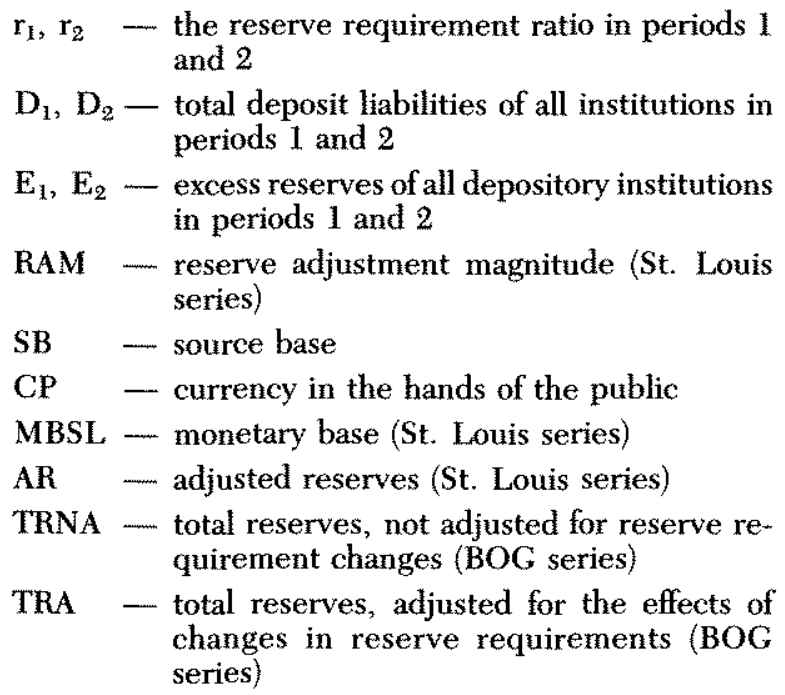

\section{Calculation of the Si: Lontis Series}

In period 1, RAM is zero, since that is the base period. RAM in period 2 is specified as

(1) $\mathrm{RAM}_{2}=r_{1} D_{2}-r_{2} D_{2}$.

The source base can be specified as the sum of currency held by the public, required reserves and excess reserves. For period 1,

(2) $\mathrm{SB}_{1}=\mathrm{CP}_{1}+\mathbf{r}_{1} \mathrm{D}_{1}+\mathrm{E}_{1}$.

Since RAM is zero in period 1 , the source base is the same as the monetary base. In period 2 ,
(3) $\mathrm{MBSL}_{2}=\mathrm{SB}_{2}+\mathrm{RAM}_{2}$

$$
\begin{aligned}
& =C P_{2}+r_{2} D_{2}+E_{2}+\left(r_{1} D_{2}-r_{2} D_{2}\right) \\
& =C P_{2}+r_{1} D_{2}+E_{2} .
\end{aligned}
$$

Adjusted reserves are calculated by subtracting currency in the hands of the public from the monetary base:

(4) $\mathrm{AR}_{2}=\mathrm{MBSL}_{2}-\mathrm{CP}_{2}$

$$
=r_{1} D_{2}+E_{2} \text {. }
$$

\section{Calcalntion of the $10 \mathrm{OC}$ Serves}

Total reserves, not adjusted for the effects of changes in reserve requirements, are specified $a^{2}$.

(5) TRNA $_{1}=r_{1} D_{1}+E_{1}$

(6) $\operatorname{TRNA}_{2}=\mathrm{r}_{2} \mathrm{D}_{2}+\mathrm{E}_{2}$.

For period 2, total reserves not adjusted for the effects of changes in reserve requirements are the same as total reserves adjusted. The method of adjusting for the effects of changes in reserve requirements is applied to total reserves in period I as follows:

$$
\text { (7) } \begin{aligned}
\mathrm{TRA}_{1} & =\mathrm{r}_{1} \mathrm{D}_{1} \cdot\left(\frac{\mathrm{r}_{2} \mathrm{D}_{2}}{\mathrm{r}_{1} \mathrm{D}_{2}}\right)+\mathrm{E}_{1} \\
& =\mathrm{r}_{2} \mathrm{D}_{1}+\mathrm{E}_{1} .
\end{aligned}
$$

Table Al summarizes the basic differences between the St. Louis and BOG series in the methods of adjusting for the effects of changes in reserve requirements. For the St. Louis series, adjusted reserves are calculated for period 2 as though the reserve requirement ratio of period 1 was in effect. For the BOG series, total reserves are calculated for period 1 as though the reserve requirement ratio of period 2 was in effect.

\section{MNIICATONS OF DUNTRENCES IN TIEATMENT OF WHE VAUPT CAST OF NONDOUND MSTITUTONS FOR THE RESERVIS MVESTPES}

Depository institutions with vault cash in excess of their required reserves are called nonbound institutions. Their vault cash in excess of required reserves is excluded from the BOG reserves series, but included in the St. Louis series. The difference in treatment of

\footnotetext{
${ }^{2}$ The excess reserves in total reserves (BOG) includes only excess reserve balances at Federal Reserve Banks. Excess vault cash at institutions with greater vault cash than required reserves is excluded from the BOC measure of total reserves, but is included in the St. Louis measure of adjusted reserves. This difference is ignored in this section to simplify the illustration.
} 


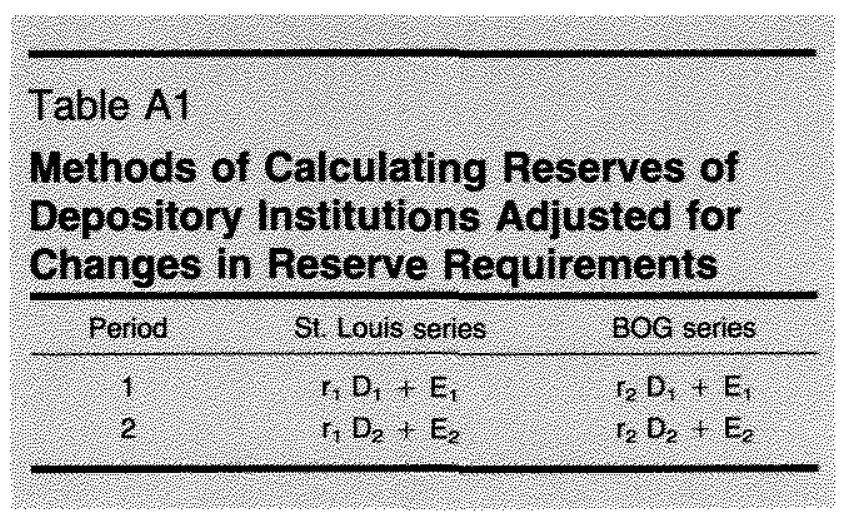

vault cash of nombound institutions causes the St. Louis reserves series to decline relative to the BOG series when the reserve requirements of nonbound institutions increase.

This effect is illustrated under the following assumptions, using some additional terms. Assumptions:

1. The base period for calculating RAM is period 1 .

2. Required reserves of nonbound institutions are increased in period 2, but vaut cash still exceeds required reserves at all of the previously nonbound institutions.

3. This increase in required reserves of nonbound in. stitutions has no effect on their demand for reserves relative to their deposit liabilities. They have the same level of deposit liabilities and hold the same amount of vault cash in period 2 as in period 1 . With higher reserve requirements, they simply have higher required reserves and lower excess vault cash.

4. Bound institutions have the same deposit liabilities and excess reserves in periods 1 and 2.

Additional terms:

$$
\begin{aligned}
& \mathrm{r}^{\mathrm{B}}-\begin{array}{c}
\text { reserve requirement ratio for bound in- } \\
\text { stitutions }
\end{array} \\
& \mathrm{r}_{1}^{\mathrm{N}}, \mathrm{r}_{2}^{\mathrm{N}}-\begin{array}{l}
\text { reserve requirement ratio for nonbound } \\
\text { institutions in periods } 1 \text { and } 2
\end{array} \\
& \mathrm{D}_{1}^{\mathrm{B}}, \mathrm{D}_{2}^{\mathrm{B}}-\begin{array}{l}
\text { deposit liabilities of bound institutions in } \\
\text { periods } 1 \text { and } 2
\end{array} \\
& \mathrm{D}_{1}^{\mathrm{N}}, \mathrm{D}_{2}^{\mathrm{N}}-\begin{array}{l}
\text { deposit liabilities of nonbound institu } \\
\text { tions in periods } 1 \text { and } 2
\end{array} \\
& \mathrm{E}_{1}^{\mathrm{B}}, \mathrm{E}_{2}^{\mathrm{B}}-\begin{array}{l}
\text { excess reserves of bound institutions in } \\
\text { periods } 1 \text { and } 2
\end{array}
\end{aligned}
$$

$V_{1}^{N}, V_{2}^{N}$ - vault cash of nonbound institutions in periods 1 and 2 by

Adjusted reserves (St. Louis) in period 1 are given

(8) $A R_{1}=r^{B} D_{1}^{B}+r_{1}^{N} D_{1}^{N}+E_{1}^{B}+E_{1}^{N}$.

Because nonbound institutions hold all of their required and excess reserves as vault cash, their excess reserves can be expressed as

(9) $\mathrm{E}_{1}^{\mathrm{N}}=\mathrm{V}_{1}^{\mathrm{N}}-\mathrm{r}_{1}^{\mathrm{N}} \mathrm{D}_{1}^{\mathrm{N}}$.

Substituting this expression for their excess reserves into the equation for adjusted reserves yields

(10) $\mathrm{AR}_{1}=\mathbf{r}^{\mathrm{B}} \mathrm{D}_{1}^{\mathrm{B}}+\mathrm{E}_{1}^{\mathrm{B}}+\mathrm{V}_{1}^{\mathrm{N}}$.

Using the same terms for period 2:

(11) $A R_{2}=r^{B} D_{2}^{B}+E_{2}^{B}+V_{2}^{N}$

$$
\begin{aligned}
& +\left(r^{B} D_{2}^{\dot{B}}+r_{1}^{N} D_{2}^{N}-r^{B} D_{2}^{B}-r_{2}^{N} D_{2}^{N}\right) \\
& =r^{B} D_{2}^{B}+E_{2}^{B}+V_{2}^{N}+\left(r_{1}^{N}-r_{2}^{N}\right) D_{2}^{N} .
\end{aligned}
$$

By the assumptions above,

(12) $\mathrm{AR}_{2}-\mathrm{AR}_{1}=\left(\mathrm{r}_{1}^{\mathrm{N}}-\mathrm{r}_{2}^{\mathrm{N}}\right) \mathrm{D}_{2}^{\mathrm{N}}$,

which is negative, because $r_{2}^{N}$ is larger than $r_{1}^{N}$.

Because total reserves (BOG) exclude excess vault cash, values of that series in periods 1 and 2 can be written as

(13) $\mathrm{TRA}_{2}=\mathrm{r}^{\mathrm{B}} \mathrm{D}_{2}^{\mathrm{B}}+\mathrm{r}_{2}^{\mathrm{N}} \mathrm{D}_{2}^{\mathrm{N}}+\mathrm{E}_{2}^{\mathrm{B}}$

(14) $\mathrm{TRA}_{1}=\mathrm{r}^{\mathrm{B}} \mathrm{D}_{1}^{\mathrm{B}}+\mathrm{r}_{1}^{\mathrm{N}} \mathrm{D}_{1}^{\mathrm{N}}\left(\frac{\mathrm{r}_{2}^{\mathrm{N}} \mathrm{D}_{2}^{\mathrm{N}}}{\mathrm{r}_{1}^{\mathrm{N}} D_{2}^{\mathrm{N}}}\right)+\mathrm{E}_{1}^{\mathrm{B}}$

$$
=r^{B} D_{1}^{B}+r_{2}^{N} D_{1}^{N}+E_{1}^{B} \text {. }
$$

Given our assumptions,

(15) $\mathrm{TRA}_{1}-\mathrm{TRA}_{2}=0$.

Thus, under our assumptions, a rise in the reserve requirement ratio of nonbound institutions causes adjusted reserves (St. Louis) to decline and total reserves (BOG) to remain unchanged. Since most of the nonbound institutions are nonmembers, this analysis indicates why a rise in reserve requirements of nonmembers tends to reduce adjusted reserves (St. Louis) relative to total reserves (BOG).

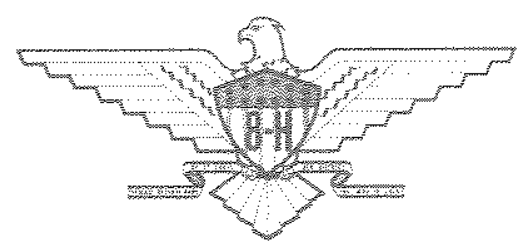

